\title{
Compulsive gaming in secondary school students from five Peruvian cities: Usage and addiction to the Pokémon GO
} game

\section{Juego compulsivo en estudiantes de secundaria de cinco ciudades peruanas: Uso y adicción al juego Pokemon GO}

Christian R. Mejia ${ }^{1}$, Lienneke S. Mena², César A. Mogollón ${ }^{3}$, Rocío Figueroa-Romero4, Edgardo N. Hernández-Calderón ${ }^{5}$ Andrés M. Aguilar-Fernández ${ }^{6}$, Jhosselyn I. Chacon ${ }^{7}$, Armando Miñan-Tapia ${ }^{8}$, Marcos Roberto Tovani-Palone ${ }^{9}$, Gustavo Hernández-Arriaga ${ }^{10}$

\begin{abstract}
Introduction: Some years ago, the Pokémon GO game became incredibly popular. However, no studies on the subject have been conducted in Peru involving vulnerable populations, such as adolescents.

Objective: To determine if the number of hours playing the Pokémon GO game is associated with Internet and/or video game addiction, as well as to other factors in secondary school students from five Peruvian cities.

Materials and methods: Cross-sectional, analytical, and multi-centric study, with a sample of 944 school students. General characteristics, including socio-educational aspects, and Internet and/or video game addiction were analyzed, as well as variables related to the use of the game, such as problems at home, with teachers, accidents, and theft.

Results: We found statistical associations between the assessed variables and increased playing time. 409 (44\%) students had an Internet addiction 215 (23\%) were addicted to video games, and 336 (49\%) spent a significant number of hours per day playing Pokémon GO. A greater number of hours playing Pokémon $\mathrm{GO}$ was associated with having a video game addiction (prevalence ratio (PR): 1,33; 95\% confidence interval (Cl): 1.07-1.65), greater use of cell phone applications (PR: 1.02; 95\% Cl: 1.01-1.03), reprimand by parents (PR: 1.09; 95\% Cl: 1.02-1.18), and reprimand for arriving late to class (PR: 1.44; 95\% Cl: 1.07-1.18). On the other hand, students who played a greater number of video games used Pokémon GO by a lower number of hours (PR: 0,98; 95\% Cl: 0.97-0.99), adjusted by the respondent's location.

Conclusion: Higher usage levels of Pokémon GO were associated with having a video game addiction, greater use of phone applications, negative repercussions from parents, and reprimand for arriving late to class.
\end{abstract}

Keywords: students, video games, Pokémon GO, Peru, addictive behavior

\footnotetext{
1 Universidad Continental, Lima, Peru.

Centro de Investigación y Estudios Médicos CIEM, Universidad Católica de Santa

María, Arequipa, Peru.

3 Sociedad Científica de Estudiantes de Medicina de Cajamarca, Universidad Nacional de Cajamarca, Cajamarca, Peru.

4 Centro de Investigación de Estudiantes de Medicina (CIESMED), Tacna, Peru.

5 Sociedad Científica de Estudiantes de Medicina de la Universidad Nacional de Piura, (SOCIEMUNP), Universidad Nacional de Piura, Piura, Peru.

6 Facultad de Medicina Humana, Universidad Ricardo Palma, Lima, Peru.

7 Asociación Médica de Investigación y Servicios en Salud, Lima, Peru.

8 Universidad Nacional Jorge Basadre Grohmann, Facultad de Ciencias de la Salud, Tacna, Peru.

9 Ribeirão Preto Medical School, University of São Paulo, Ribeirão Preto, Brazil.

${ }^{10}$ Facultad de Medicina y Cirugía, Universidad Católica de Honduras, San Pedro Sula, Honduras.
}

Correspondence: Christian R. Mejia

Av. Las Palmeras 5713 - Lima, Perú.

E-mail: christian.mejia.md@gmail.com

Received: 26 Oct 2018, Accepted: 1 Nov 2019

(C) 2019 by the authors; licensee Modestum Ltd., UK. This article is an open access article distributed under the terms and conditions of the Creative Commons Attribution License (http://creativecommons.org/licenses/by/4.0/). 


\section{RESUMEN}

Introducción: Hace algunos años, el juego Pokemon GO se hizo increíblemente popular. Sin embargo, no se han realizado estudios sobre el tema en Perú que involucren a poblaciones vulnerables, como los adolescentes.

Objetivo: Determinar si el número de horas que se juega Pokemon GO está asociado con la adicción a Internet y/o videojuegos, y otros factores en estudiantes de secundaria de cinco ciudades peruanas.

Materiales y métodos: Estudio transversal, analítico y multicéntrico, con una muestra de 944 estudiantes escolares. Se analizaron las características generales, incluidos los aspectos socioeducativos y la adicción a Internet y/o videojuegos, así como las variables relacionadas con el uso del juego, como problemas en el hogar, con los maestros, accidentes y robos.

Resultados: Encontramos asociaciones estadísticas entre las variables evaluadas y el aumento del tiempo de juego, 409 (44\%) estudiantes tenían una adicción a Internet, 215 (23\%) eran adictos a los videojuegos y 336 (49\%) pasaron un número significativo de horas por día jugando Pokemon GO. Un mayor número de horas jugando Pokemon GO se asoció con una adicción a los videojuegos (razón de prevalencia (RP): 1,33; intervalo de confianza (IC) 95\%: 1,07-1,65), un mayor uso de aplicaciones de teléfonos celulares (RP: 1,02; IC 95\%: 1,01-1,03), amonestación por parte de los padres (RP: 1,09; IC 95\%: 1,02-1,18) y amonestación por llegar tarde a la clase (RP: 1,44; IC 95\%: 1,07-1,18). Por otro lado, los estudiantes que jugaron una mayor cantidad de videojuegos utilizaron Pokemon GO por un menor número de horas (RP: 0,98; IC 95\%: 0,97-0,99), ajustado por la ubicación del encuestado. Conclusiones: Los niveles de uso más altos del Pokemon GO se asociaron con la adicción a los videojuegos, un mayor uso de aplicaciones de teléfonos, repercusiones negativas de padres y amonestación por llegar tarde a la clase.

Palabras clave: estudiantes, videojuegos, Pokemon GO, Perú, comportamiento adictivo

\section{INTRODUCTION}

Pokémon GO became very popular in 2016 and its use was disseminated to many parts of the world. This game has been offered via a cell phone application, with some elements of reality (1). According to the literature, there may be some benefits of using Pokémon GO, including combating obesity and diabetes (2), changing a sedentary lifestyle $(3,4)$, promoting physical activity (5), lowering the risk of cardiovascular diseases (6), greater bonding with other people or family members (7), and combating stress and other mental health problems $(8,9)$.

On the other hand, problems have been also reported as a result of excessive and uncontrolled use of this game, such as addiction (10), accidents $(11,12)$, invasion of private property, and physical ergonomic problems (13). However, up till now, few studies have investigated variables associated with playing Pokémon GO in Peru, especially in minors. In the present study, we determine if the number of hours playing the Pokémon GO game is associated with Internet and/or video game addiction, as well as to other factors in secondary school students from five Peruvian cities.

\section{MATERIALS AND METHODS}

\section{Design, Participants, and Settings}

This cross-sectional, analytical, and multi-centric study was carried out in five important cities of Peru, of which three are coastal cities: Piura (located in the north coast, with 59 respondents), Lima (located in the central coast and it is the Peruvian capital, with 155 respondents), and Tacna (located in the south coast, with 168 respondents). The other two are highland cities: Cajamarca (located in the northern highlands, with 361 respondents) and Arequipa (located in the southern highlands, with 201 respondents). These are among the 10 most important and highest-populated cities in Peru.

\section{Sample and Data Collection}

In the pilot study, we calculated that it would be necessary to include at least 899 students to find a minimum difference of $6 \%$ in the proportion of respondents, for a power of $95 \%$, using an alpha value of 0.05 . This was due to the fact that the study was drafted in a descriptive and analytical component of data.

The sample included secondary school students enrolled in the second semester of the year 2016, who voluntarily agreed to participate in the study and answered more than $70 \%$ of the questions. We excluded one survey from the analysis, which was not related to the main research question (playing Pokémon GO).

\section{Variables}

The main variable assessed was whether the students played the Pokémon GO game. Three different situations were considered: the adolescent did not play the game, played the game for a few hours or moderately, played the game for several hours (this category was generated based on the upper tertile with respect to the number of hours played per day). Only the categories of low use (two lower tertiles) and high use (upper tertile) were used for statistical analysis. 
Also, we recorded whether the students had been reprimanded by their parents, teachers, or for being late for class because of the game. They were directly asked if this had occurred during the last two months as a result of playing Pokémon GO (this period corresponds to the release of the game in Peru and when it became popular). In addition, socio-educational data were collected from the students (gender, age, and school grade), and they were asked about the number of cell phone applications and video games used (both variables were quantitatively measured).

\section{Research Instrument}

Addiction to using the Internet and video games was also evaluated with the MULTICAGE CAD-4 test. This survey is a simple and easy to understand screening instrument, which has been administered and validated within and outside Peru $(14,15)$. Addiction to the Internet or video games was defined as having two or more positive responses in the four questions of the MULTICAGE CAD-4 test. According to this instrument, 0-1 positive responses indicate that addiction is not present.

\section{Ethical Aspects}

The present study was based on a previous project, whose objective was to measure the effect of an educational intervention on students (approved by the Ethics and Research Committee of the National Mother-Child Teaching Hospital "San Bartolomé", Lima, Peru: Office Number: 266 File: 15030). To assess the effects of the Pokémon GO game an amendment was requested in August 2016. After approval by the Ethics Committee, interviewers were recruited in each city, and all were trained online. Moreover, permission was requested of all participant students.

\section{Data Analysis}

We first carried out a process of data cleaning and quality control for the statistical analysis using a Microsoft Excel spreadsheet (version 2013 for Windows). Later data were exported to STATA statistical software version 11.1 (STATA Corp LP, College Station, TX, USA), and an initial descriptive analysis was performed. We then moved to analytical statistics using chi-square test (test for the interaction of the categorical variables) and ANOVA (test for the interaction of age and school grade). Finally, we obtained the prevalence ratios (PR), 95\% confidence intervals (Cl), and p-values using generalized linear models. For this purpose, a Poisson regression and a log link function were used together with robust models (with adjustments for each city). Statistical significance was set at a p-value of $<0.05$.

\section{RESULTS}

We found that of the 944 surveyed students, 44\% (409) had an Internet addiction and 23\% (215) a video game addiction. With regards to the respondents who played Pokémon GO, 49\% (336) spent a large time interacting with the game (two or more hours per day). Figure 1 shows the frequencies for respondents in each city. 


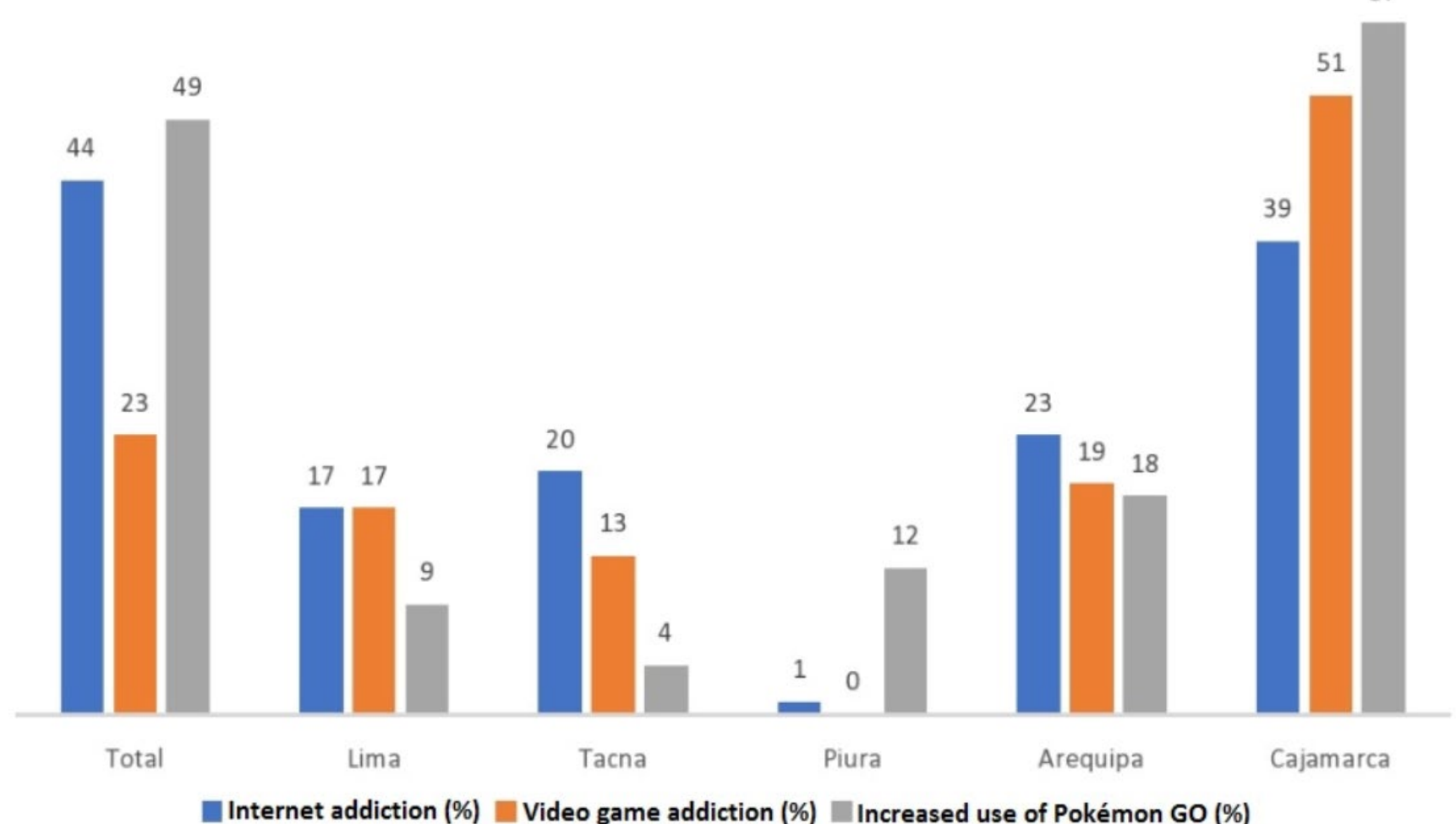

Note: Percentages were obtained based on respondents who provided two or more positive responses in the MULTICAGE CAD-4 test, which indicated risks for addiction

Figure 1: Percentage of Internet addiction, video game addiction, and increased use of Pokémon GO (two or more hours per day) in secondary school students by city

The median number of hours that the students played Pokémon GO was 1.5 (interquartile range: 1-2 hours per day). We also found that there were some short-term consequences related to this game, as $9 \%$ of the respondents (63) were reprimanded by their parents for playing Pokémon GO, 3\% (23) by their teachers, and $4 \%$ (31) for being late to class because of the game. Moreover, $6.2 \%$ of the students (58) reported that they had accidents while playing Pokémon GO (62.8\% due to falls, $16.7 \%$ to crashes, and $21.6 \%$ to other causes) and 111 respondents (11.9\%) said they had been victims of theft while playing the game.

As Table 1 shows, statistical differences were found concerning the use of Pokémon GO according to gender ( $p$ $<0.001)$, age $(p<0.001)$, school grade $(p<0.001)$, video game addiction $(p<0.001)$, time spent using cell phone applications ( $p$ <.001), time spent using video game (p: 0.005), reprimand by parents ( $p: 0.025)$, and reprimand for arriving late to class (p: 0.034) (Table 1).

The multivariate analysis adjusted by respondent location is included in Table 2. According to these data, a greater number of hours playing the game was associated with video game addiction (PR: 1.33; 95\% Cl: 1.07-1.65), greater use of cell phone applications (PR: 1.02; 95\% Cl: 1.01-1.03), reprimand by parents (PR: 1.09; 95\% Cl: 1.02-1.18), and reprimand for arriving late to class (PR: 1.44; 95\% Cl: 1.07-1.18). Furthermore, playing video games for more hours was associated with a lower number of hours playing Pokémon GO (PR: 0.98; 95\% Cl: 0.97-0.99) (Table 2).

There was a statistically significant difference in internet usage in the city of Piura (Piura versus Lima $(p<0.001)$, versus Tacna $(p<0.001)$, versus Cajamarca $(p<0.001)$, and versus Arequipa $(p<0.001))$. Regarding the differences in video game usage, we verified that the city of Piura presented differences compared to Lima $(p=0.002)$, Cajamarca $(p<0.001)$ and Arequipa ( $p=0.009$ ), while the city of Tacna presented difference in comparison with Cajamarca $(p=0.014)$. These results of differences in internet and video game usage according the cities were obtained with ANOVA and adjusted by Bonferroni correction. 
Table 1: Socio-educational and other characteristics of secondary school students according to the use of the Pokémon GO game

\begin{tabular}{|c|c|c|c|c|}
\hline \multirow[b]{2}{*}{ Variables } & \multicolumn{3}{|c|}{ Pokémon Go game n(\%) } & \multirow[b]{2}{*}{ p-value } \\
\hline & $\begin{array}{c}\text { Playing "a lot" (less than } \\
2 \text { hours per day) }+\end{array}$ & $\begin{array}{l}\text { Playing "a little" (more } \\
\text { than } 2 \text { hours per day) }+\end{array}$ & No use & \\
\hline \multicolumn{5}{|l|}{ Gender } \\
\hline Male & $193(54.5)$ & $205(61.2)$ & $95(37.4)$ & $<0.001$ \\
\hline Female & $161(45,5)$ & $130(38,8)$ & $159(62.6)$ & \\
\hline Age $\left(\right.$ years) ${ }^{*}$ & $15(14-16)$ & $14(13-15)$ & $15(14-16)$ & $<0.001$ \\
\hline School grade* & $3(2-5)$ & $3(2-4)$ & $4(3-5)$ & $<0.001$ \\
\hline \multicolumn{5}{|l|}{ Having an addiction to } \\
\hline Internet & $143(40.5)$ & $149(44.4)$ & $117(47.2)$ & 0.255 \\
\hline Video games & $67(19.0)$ & 107(31.9) & $41(16.7)$ & $<0.001$ \\
\hline \multicolumn{5}{|l|}{ Use of (quantity)* } \\
\hline Phone applications & $2(1-4)$ & $3(1-5)$ & $0(0-2)$ & $<0.001$ \\
\hline Video games & $2(0-3)$ & $2(1-4)$ & $0(0-2)$ & 0.005 \\
\hline \multicolumn{5}{|l|}{ Reprimands by } \\
\hline Parents & $21(6.0)$ & $35(10.4)$ & $7(15.6)$ & 0.025 \\
\hline Teachers & $9(2.6)$ & $11(3.3)$ & $3(6.5)$ & 0.339 \\
\hline For being late to class & $8(2.3)$ & $21(6.3)$ & $2(4.4)$ & 0.034 \\
\hline
\end{tabular}

${ }^{*}$ Median and interquartile ranges. ${ }^{\dagger}$ The number of hours was calculated based on the 50th percentile. Values below the 50th percentile were considered as "low use". P-values were obtained using the chi-squared test (for the categorical variables) and ANOVA (for age and school grade). Playing "a lot" was defined as being in the top tertile of all responses, and playing "a little" was defined as falling within the two lower tertiles

Table 2: Multivariate analysis of factors associated with higher levels of Pokémon GO usage by secondary school students from five Peruvian cities

\begin{tabular}{|c|c|c|}
\hline \multirow{2}{*}{ Variables } & \multicolumn{2}{|c|}{ Prevalence ratio (95\% Confidence Interval) } \\
\hline & Bivariate analysis & Multivariate analysis \\
\hline Female & $0.87(0.69-1.09)$ & $0.90(0.75-1.08)$ \\
\hline Age $\left(\right.$ years) ${ }^{\star}$ & $0.93(0.88-0.98)^{\star}$ & $0.95(0.85-1.07)$ \\
\hline School grade* & $0.92(0.86-0.98)^{\star}$ & $0.97(0.86-1.08)$ \\
\hline \multicolumn{3}{|l|}{ Addiction to } \\
\hline Internet & $1.08(0.86-1.37)$ & $1.01(0.78-1.31)$ \\
\hline Video games & $1.38(1.19-1.61)^{\star}$ & $1.33(1.07-1.65)^{\star}$ \\
\hline \multicolumn{3}{|l|}{ Use of (quantity)* } \\
\hline Phone applications & $1.02(1.01-1.03)^{\star}$ & $1.02(1.01-1.03)^{\star}$ \\
\hline Video games & $1.00(0.99-1.01)$ & $0.98(0.97-0.99)^{\star}$ \\
\hline \multicolumn{3}{|l|}{ Reprimands by } \\
\hline Parents & $1.31(1.14-1.52)^{\star}$ & $1.09(1.02-1.18)^{\star}$ \\
\hline Teachers & $1.13(0.82-1.54)$ & $0.93(0.73-1.18)$ \\
\hline Being late to class & $1.52(1.22-1.88)^{\star}$ & $1.44(1.07-1.94)^{\star}$ \\
\hline
\end{tabular}

*P-value $<0.05$. Higher usage levels of Pokémon GO was defined as values falling within the top tertile of all responses, as opposed to values falling within the two lower tertiles

\section{DISCUSSION}

According to the results of our study, there was game addiction generated by Pokémon GO, given that a great number of players and of the time that they invested in this game was observed.

We found also that half of the respondents who played Pokémon GO used it for more than two hours a day. This was considered excessive use, and shows that this type of game can be used improperly by populations like the one was studied. Previous studies on primary school students have confirmed this fact, reporting that $81 \%$ of respondents allocated more than one hour a day to playing video games (16).

Another relevant finding in the present study was that the students who spent more hours playing Pokémon GO had a greater addiction to other video games and made greater use of cell phone applications. Results from other studies have shown an important percentage of students addicted to video games in Peru (17), Colombia (18), Spain (19) and Singapore (20), and addicted to Internet in Peru (21). A research paper published in 2015 found a shorter time used to play video games, which was 10 to 250 minutes in $47 \%$ of men and $58 \%$ of women (17). This difference may be due to the chosen game in terms of novelty or preference, and to the number of hours available to play it. 
We do not believe that the difference in the level of video game usage in our study is the result of using the MULTICAGE CAD-4 scale, since Pokémon GO took the world by storm from the moment it came out, as evidenced by several publications. Searching in the PubMed database (search terms: Pokémon [All Fields] AND GO [All Fields]) we found that before the game was launched there was only one publication about it (from the year 2013), but since 2016 and to date (May 21, 2018) more than 50 studies about the subject matter have been published.

However, our results can have been influenced by academic and home obligations of the participants, given that the study populations should be different. It is noteworthy, nevertheless, that the present paper is the first on this specific subject involving the Pokémon GO game in Peru.

Also, four out of 10 students that participated in this study had an Internet addiction while two out of 10 were addicted to video games, which reveals a population susceptible to technology addictions. In a research conducted in adolescents and young adults people, the consequences of the use of information and communication technologies, including the Internet, cell phones, and video games were assessed. Its results showed that $10 \%$ of participants were addicted to all studied technologies, and $2 \%$ suffered from two addictions simultaneously (19), which corroborates our findings. In the present study, these results should be due to other factors, such as safety during the game, especially considering that some large cities may have a high rate of theft and related incidents (18).

Although our findings indicate that the inappropriate use of Pokémon GO is often associated to the number of played hours and other addictions, a study in a population of university students from Huancayo, Peru showed that high levels of smartphone usage should not have negative consequences (when used sparingly and without Internet) (20). In this connection, it is important that specialists take this information into consideration for appropriate diagnosis of technology addiction in students.

It should also be borne in mind that the Pokémon GO game had a peak of success at the time of its launch with a large number of players worldwide. Nonetheless, the number of players decreased as time passed. Our research collected data only during months of the peak of game's success in Peru. Despite at present this game is hardly used, we observed that it had a great reception by school students, who can have addictions (measured through Student's t-test) and problems related to its use.

Another important result found by us was the significant ocurrence of reprimands from parents and for arriving late to class. The results of other researchers have also shown that a greater use of the Pokémon GO game results in students receiving more reprimands from parents and due to being late to their classes. This suggests that the inappropriate use of the game can have negative consequences in the short and long term (11,21). In addition, Burgess, Stermer and Burgess (2012) found that video game players had lower average grades, but this finding varied by gender (22). On the other hand, Chacón Cuberos et al. (2017) reported that video game use habits is associated to a low level of use and attraction to games by most students, while only one-fifth of the students assessed in their study showed a medium or high level of video game playing involvement. However, the excessive use of video games had also a negative influence on the academic performance of students (23). In terms of physical activity, some studies have shown that people who use the Pokémon GO game have greater motivation to exercise (22). Nevertheless, the motivation increase should be temporary (24) and it should be balanced against the negative repercussions related to the game.

The selection bias was a limitation of the current study, because there was no random sampling that would allow us to generalize the results to the schools or locations. However, our study should be considered as a preliminary investigation, which assessed the factors associated with the use of the Pokémon GO game (the study did not attempt to report an analysis of prevalence specific to the game). Further research is recommended to elucidate more aspects of this game as well as other games available to minors, including other consequences in the short, medium, and longterm. Furthermore, the primary validation of the MULTICAGE CAD-4 test used by us was carried out in Spain, so more studies are needed to utilize this instrument with more reliability in Peruvian research (only one study was found) (15). It should also be taken into account that the instrument used in this study does not allow for a definitive diagnosis of addiction, given that it is generally used for initial screening.

We must also look to the prevalence of addictions with caution, since although it was obtained from a validated instrument, this result was from self-reporting, and thus it can be overestimated. It is known that research measurement instruments can have problems of information bias, however they are still considered good features for the collection of information in large investigations. This is valid in our case, even in the absence of a psychiatrist or other health professional to make a direct assessment.

In short, we conclude that almost half of the school's students that participated in our study used Pokémon GO excessively and a high percentage of students were addicted to the Internet and video games. Higher usage levels of 
the game were associated with having a video game addiction, greater use of phone applications, negative repercussions from parents, and reprimand for arriving late to class.

\section{ACKNOWLEDGEMENT}

We are grateful to Evelyn E. Bautista (Sociedad Científica de Estudiantes de Medicina de Cajamarca, Universidad Nacional de Cajamarca, Cajamarca, Peru) for her assistance in conducting the surveys.

\section{REFERENCES}

1. Gilbert B. Pokémon $\mathrm{GO}$ has been downloaded over 500 million times: business Insider [online]. 2016 sep. 07 [accessed 2019-08-10]. Available from: https://www.businessinsider.com/pokemon-go-500-million-downloads2016-9

2. Ghosh A, Misra A. Pokémon GO, obesity and diabetes: a perspective from India. Diabetes Technol Ther. 2016;18(11):725-6. https://doi.org/10.1089/dia.2016.0303 PMid:27753510

3. Wong FY. Influence of Pokémon GO on physical activity levels of university players: a cross-sectional study. Int J Health Geogr. 2017;16(1):8.

4. Nigg CR, Mateo DJ, An J. Pokémon GO may increase physical activity and decrease sedentary behaviors. Am J Public Health. 2017;107(1):37-8. https://doi.org/10.2105/AJPH.2016.303532 PMid:27854536 PMCid:PMC5308176

5. Althoff T, White RW, Horvitz E. Influence of Pokémon GO on physical activity: study and implications. J Med Internet Res. 2016;18(12):e315. https://doi.org/10.2196/jmir.6759 PMid:27923778 PMCid:PMC5174727

6. Krittanawong C, Aydar M, Kitai T. Pokémon GO: digital health interventions to reduce cardiovascular risk. Cardiol Young. 2017;27(8):1625-6. https://doi.org/10.1017/S1047951117000749 PMid:28414007

7. Tateno M, Skokauskas N, Kato TA, Teo AR, Guerrero APS. New game software (Pokémon GO) may help youth with severe social withdrawal, hikikomori. Psychiatry Res. 2016;246:848-9. https://doi.org/10.1016/j.psychres.2016.10.038 PMid:27817905 PMCid:PMC5573581

8. Watanabe K, Kawakami N, Imamura K, et al. Pokémon GO and psychological distress, physical complaints, and work performance among adult workers: a retrospective cohort study. Sci Rep. 2017;7(1):10758. https://doi.org/10.1038/s41598-017-11176-2 PMid:28883633 PMCid:PMC5589944

9. Reynolds LM, Hodge P, Simpson A. Serious games for mental health. J Psychiatr Ment Health Nurs. 2017;24(4):183-4. https://doi.org/10.1111/jpm.12385 PMid:28295887

10. Sack D. The toughest part of Pokémon GO: stopping 2016 [online]. 2016 jul. 14 [accessed 2019-08-10]. Available from: https://www.psychologytoday.com/intl/blog/where-science-meets-the-steps/201607/the-toughest-partpok-mon-go-stopping

11. Pourmand $A$, Lombardi $K$, Kuhl E, O'Connell F. Videogame-related illness and injury: a review of the literature and predictions for Pokémon GO! Games Health J. 2017;6(1):9-18. https://doi.org/10.1089/g4h.2016.0090 PMid:28135114

12. Ayers JW, Leas EC, Dredze M, Allem JP, Grabowski JG, Hill L. Pokémon GO-a new distraction for drivers and pedestrians. JAMA Intern Med. 2016;176(12):1865-6. https://doi.org/10.1001/jamainternmed.2016.6274 PMid:27635638

13. Shaheen Afat AM, Abdel Rahman Samia AA. Cumulative musculoskeletal disorders related to computer products use in arabic children and adolescents. Indian J Physiother Occup Ther. 2010; 4(2):1-5.

14. Pedrero Pérez EJ, Rodríguez Monje MT, Gallardo Alonso F, Fernández Girón M, Pérez López M, Chicharro Romero J. Validación de un instrumento para la detección de trastornos de control de impulsosy adicciones: el MULTICAGE CAD-4. Trastor Adict. 2007;9(4):269-79. https://doi.org/10.1016/S1575-0973(07)75656-8

15. Benites-Gamboa D, Chacón Jl, Pacheco-Berrios N, et al. Trastornos de control de impulsos y adicciones según universidad de estudiantes de medicina: multicéntrico de diecinueve sedes en latinoamérica [online]. 2016 [accessed 2019-08-10]. Available from: http://v-beta.urp.edu.pe/pdf/id/5243/n/poster-dayanne.pdf 
16. Remache Ruiz I. Los videojuegos y su incidencia en el rendimiento académico de los/las estudiantes del quinto y sexto grado de educación general básica de la unidad educativa CEC de la ciudad de Latacunga, provincia de Cotopaxi [research work] [online]. Ambato: Universidad Técnica de Ambato, Facultad de Ciencias Humanas y de la Educación Carrera de Educación Básica; 2013 [accessed 2019-08-11]. Available from: http://repositorio.uta.edu.ec/bitstream/123456789/6065/1/FCHE-SEB-1026.pdf

17. Fisher de la Vega LE, Correa GB, Sánchez DC. Contribución de la mercadotecnia en la utilización del smartphone para videojuegos, convirtiéndola en una posible adicción en los jóvenes. Eur Sci J. 2015;11(8):35-45.

18. Instituto Nacional de Estadística e Informática. Informe técnico - Estadísticas de seguridad ciudadana: JulioDiciembre 2016 [online]. Lima: Biblioteca Virtual del Instituto Nacional de Estadística e Informática; 2016-2017 [accessed 2019-08-10]. Available from: https://www.inei.gob.pe/biblioteca-virtual/boletines/estadisticas-deseguridad-ciudadana/2/

19. García-Oliva C, Piqueras JA, Marzo JC. Uso problemático de Internet, el móvil y los videojuegos en una muestra de adolescentes alicantinos. Health and Addictions: Salud y Drogas. 2017;17(2):189-200. https://doi.org/10.21134/haaj.v17i2.331

20. Mejia CR, Flores SD, Verastegui-Díaz A, et al. Uso del smartphone y de facebook asociado a la autopercepción del rendimiento académico en estudiantes de Medicina peruanos. Revista Cubana Inf Cienc Salud. 2017;28(1):7788.

21. Rasche P, Schlomann A, Mertens A. Who is still playing Pokémon GO? A web-based survey. JMIR Serious Games. 2017;5(2):e7. https://doi.org/10.2196/games.7197 PMid:28381393 PMCid:PMC5399220

22. Burgess $S R$, Stermer SP, Burgess MCR. Video game playing and academic performance in college students. College Student Journal. 2012;46(2):376-87.

23. Chacón Cuberos R, Zurita Ortega F, Martínez Martínez A, Castro Sánchez M, Espejo Garcés T, Pinel Martínez C. Relación entre factores académicos y consumo de videojuegos en universitarios. Un modelo de regresión. PixelBit. Revista de Medios y Educación. 2017;(50):109-21. https://doi.org/10.12795/pixelbit.2017.i50.07

24. Howe KB, Suharlim C, Ueda P, Howe D, Kawachi I, Rimm EB. Gotta catch'em all! Pokémon GO and physical activity among young adults: difference in differences study. BMJ. 2016;355:i6270. https://doi.org/10.1136/bmj.i6270 PMid:27965211 PMCid:PMC5154977

$\diamond \diamond \diamond \diamond \diamond \diamond \diamond$

http://www.ejgm.co.uk 